\title{
Down-regulation of transcription elogation factor $A$ (SII) like 4 (TCEAL4) in anaplastic thyroid cancer
} Junko Akaishi ${ }^{1,2}$, Masamitsu Onda*1, Junichi Okamoto ${ }^{1,2}$, Shizuyo Miyamoto ${ }^{1}$, Mitsuji Nagahama ${ }^{3}$, Kouichi Ito ${ }^{3}$, Akira Yoshida ${ }^{4}$ and Kazuo Shimizu²

Address: ${ }^{1}$ Department of Molecular Biology, Institute of Gerontology, Nippon Medical School, Kanagawa, Japan, ${ }^{2}$ Department of Second Surgery, Nippon Medical School, Tokyo, Japan, ${ }^{3}$ Department of Surgery, Ito Hospital, Tokyo, Japan and ${ }^{4}$ Department of Surgery, Kanagawa Prefectual Cancer Center, Kanagawa, Japan

Email: Junko Akaishi - s4067@nms.ac.jp; Masamitsu Onda* - monda@nms.ac.jp; Junichi Okamoto - s3028@nms.ac.jp; Shizuyo Miyamoto - shizuyo@totoro.cc; Mitsuji Nagahama - m-nagahama@ito-hospital.jp; Kouichi Ito - k-ito@itohospital.jp; Akira Yoshida - ayoshida@kcch.jp; Kazuo Shimizu - kshimizu@nms.ac.jp

* Corresponding author

Published: 0I November 2006

BMC Cancer 2006, 6:260 doi:10.1 186/|47|-2407-6-260
Received: 19 January 2006

Accepted: 0I November 2006

This article is available from: http://www.biomedcentral.com//47I-2407/6/260

(C) 2006 Akaishi et al; licensee BioMed Central Ltd.

This is an Open Access article distributed under the terms of the Creative Commons Attribution License (http://creativecommons.org/licenses/by/2.0), which permits unrestricted use, distribution, and reproduction in any medium, provided the original work is properly cited.

\begin{abstract}
Background: Anaplastic thyroid cancer (ATC) is one of the most aggressive human malignancies and appears to arise mainly from transformation of pre-existing differentiated thyroid cancer (DTC). However, the carcinogenic mechanism of anaplastic transformation remains unclear. Previously, we investigated specific genes related to ATC based on gene expression profiling using cDNA microarray analysis. One of these genes, transcription elongation factor A (SII)-like 4 (TCEAL4), encodes a member of the transcription elongation factor A (SII)-like gene family. The detailed function of TCEAL4 has not been described nor has any association between this gene and human cancers been reported previously.
\end{abstract}

Methods: To investigate the role of TCEAL4 in ATC carcinogenesis, we examined expression levels of TCEAL4 in ACLs as well as in other types of thyroid cancers and normal human tissue.

Results: Expression of TCEAL4 was down-regulated in all II ACLs as compared to either normal thyroid tissues or papillary and follicular thyroid cancerous tissues. TCEAL4 was expressed ubiquitously in all normal human tissues tested.

Conclusion: To our knowledge, this is the first report of altered TCEAL4 expression in human cancers. We suggest that loss of TCEAL4 expression might be associated with development of ATC from DTC. Further functional studies are required.

\section{Background}

Anaplastic thyroid cancer (ATC) is one of the most lethal tumors of all human malignancies [1-3]. ATC is well known to often arise from transformation of differentiated thyroid cancer (DTC) of the papillary or follicular type [1-5]. However, little is known about the genetic mechanisms of the transformation of DTC to ATC. We have been attempting to identify new diagnostic markers and drug-target molecules in ATC by cDNA microarray technology, and lately have reported specific changes in 
expression of several genes in ATCs and cell lines derived from anaplastic thyroid cancers (ACL)s [6].

In this paper, we describe a novel member of the group of down-regulated genes that was identified by expression profiling: transcription elongation factor A (SII)-like 4 (TCEAL4). NCBI accession number NM_024863, which is located a Xq22.1. The coding sequence is 1077 basepairs and the mRNA consists of 1516 basespairs according to the NCBI "Gene" database (Gene ID 79921). TCEAL4 encodes a member of the transcription elongation factor A (SII)-like (TCEAL) gene family. Members of this family contain TFA domains and may work as nuclear phosphoproteins that modulate transcription in a promoter context-dependent manner [7-9]. To date, genetic alterations of TCEAL4 in human cancers have not been described. In this study, we examined expression levels of TCEAL4 in anaplastic thyroid cancers as well as other types of thyroid cancers and normal thyroid tissue. Expression of TCEAL4 was down-regulated in anaplastic thyroid cancers as compared to either normal thyroid tissue or differentiated thyroid cancer tissue. Therefore, we attempted to clarify the mechanism of down-regulation of TCEAL4 in ATC, leading to predictions about the function of this gene.

\section{Methods}

\section{Primary thyroid tissue samples}

Primary thyroid cancer tissues were obtained from patients undergoing surgery. Normal thyroid- gland tissues were collected from patients who received surgery for papillary thyroid cancer at Ito Hospital, Tokyo. All patients had given informed consent according to guidelines approved by the Institutional Research Board. Dissected samples were frozen immediately after surgery and stored at $-80^{\circ} \mathrm{C}$ until needed.

\section{Cell lines}

Eleven cell lines derived from human anaplastic thyroid cancers were used for this study: 8305c, 8505c, ARO, FRO, TTA1, TTA2, TTA3, KTA1, KTA2, KTA3, and KTA4. The cell lines $8305 \mathrm{C}$ and $8505 \mathrm{c}$ were maintained in Dulbecco's Modified Eagle Medium (Invitrogen, Carlsbad, CA, USA) and ARO and FRO were maintained in Minimum Essential Medium (MEM). The other seven cell lines were grown in RPMI 1640. Papillary thyroid cancer cells (NPA) and follicular thyroid cancer cells (WRO) were cultured in RPMI 1640. All media contained $10 \%$ fetal bovine serum (FBS) without antibiotics. The cells were cultured in a $37^{\circ} \mathrm{C}$ incubator under $5 \% \mathrm{CO}_{2}$. In addition, to investigate TCEAL4 expression in other cancer cell lines, we examined 91 cancer cell lines, including hepatic cell carcinoma (SK-HEP-1, Hep G2, C-HC-4, Hep-KANO CL2, Hep-TABATA, HuH7, HT17, Li-7, PLC/PRF/5, Hep38, WRL68, Chang Liver, C3A) gastric cancers (HuGCOOHIRA, AZ521, H-111-TC, SH-10-TC, MKN-7, NUGC-
4), colon cancers (DLD-1, SW480, HCT-15, WiDr), pancreatic cancers (MIA Paca2, PK8), breast cancers (MDAMB-453, CRL1500, YMB-1-E, MCF7, and HBL100), ovarian cancers (CAOV-3, SK-OV-3, OVCAR-3, OV-1063, OVK18), cervical cancers (SIHA, HT-3, D98-AH2, Hela TG, Hela, Ca Ski, Me-180, Hela.P3), lung cancers (RERFLC AI, PC-14, A549, EBC-1, LU65, LU99, LK-2), urinary bladder cancers (5637, T24, EJ-1), renal cell carcinomas (OS-RC-2, RCC10RGB, VMRC-RCW, Caki-1), bile duct cancers (HuH-28, TFK-1), osteosarcomas (MG-63, Saos02, HuO-3N1, U-2OS), neuroblastoma (IMR-32, NH-12, SCCH-26, NB-1), glioblastomas, brain cancers (TE671, U-138MG, U-373MG, U-118MG, KG-1-C, GI-1, U251, SW1088, Daoy, DBTRG-05MG, D283 Med, A172, T98G, u87MG, u251MG, SNB19, uw18, uw228).

\section{RNA extraction and cDNA preparation}

RNA was extracted as described previously [6]. Briefly, thyroid tissues and cell lines that were collected by trypsinization were homogenized with TRIZOL (Invitrogen, Carlsbad, CA, USA) following the manufacturer's instructions. One microgram of extracted RNA was separated by electrophoresis in $3.0 \%$ formaldehyde denaturing gels to assess RNA quality (RNA degradation). Samples with the ratio of $28 \mathrm{~S} / 18 \mathrm{~S}$ over 1.7 were selected for densitometry. In brief, the intensity of each band was evaluated with Alphaimager (AlphaInonotech, San Leandro, CA, USA). RNA was purified using an RNeasy kit (QIAGEN, Valencia, CA, USA) to eliminate DNA contamination. CDNA was reverse-transcribed from $1 \mu \mathrm{g}$ of total RNA utilizing standard methodology.

\section{Semi-quantitative-PCR (SQ-PCR)}

To adjust the amount of transcribed cDNA, GAPDH was selected as an internal control and SQ-PCR was performed as previously described [6]. All primer sequences are shown in Table 1. All primers were designed with Primer 3 after sequence information was obtained from NCBI GenBank. Each SQ-PCR experiment was performed with 1 $\mu \mathrm{l}$ of cDNA as template, $5 \mathrm{U}$ of Takara EX Taq (Takara, Otsu, Japan), $1 \times$ PCR buffer (10 mM Tris-HCl, $50 \mathrm{mM}$ $\mathrm{KCl}$, and $1.5 \mathrm{mM} \mathrm{MgCl}$ ), $10 \mathrm{nM}$ dNTPs, and $10 \mathrm{pmol}$ each of the forward and reverse primers in a $30 \mu \mathrm{l}$ total reaction mixture. The PCR conditions $94^{\circ} \mathrm{C}$ for 2 minutes, followed by, $94^{\circ} \mathrm{C}$ for 30 seconds, $60^{\circ} \mathrm{C}$ for 30 seconds, and $72^{\circ} \mathrm{C}$ for 30 seconds for, 30 cycles in a Thermal Cycler PT-200 (MJ Research Inc., Waltham, MA).

For the evaluation of gene expression between thyroid cancers and normal thyroid -gland tissues, a 2.0\% agarose gel was used to separate $10 \mu \mathrm{l}$ of SQ-PCR product, which was visualized by ethidium bromide staining. The band intensity for each sample was measured by AlphaImager 3300 (AlphaInonotech) after background subtraction. A 
Table I: Primers for semi-quantitative and quantitative RT-PCR

\begin{tabular}{lll}
\hline Gene & Forward primer $\left(5^{\prime}-3^{\prime}\right)$ & Reverse primer $\left(5^{\prime}-3^{\prime}\right)$ \\
\hline GAPDH & ggaaggtgaaggtcggagt & tgggtggaatcatattggaa \\
TCEAL4 (semi-quantitative-PCR) & ctggctcattacctcaaggagta & agtggacacagctttcagaattg \\
TCEAL4 (quantitative-PCR) & gaaaaggaggggaaatctcg & ggctttctctcgtcttgtgg \\
\hline
\end{tabular}

16-bit imaging score was acquired from each sample. All SQ-PCR experiments were done in duplicate.

\section{Quantitative RT-PCR (Q-PCR)}

Q-PCR experiments were performed with an ABI PRISM 7700 Sequence Detector (Applied Biosystems, Foster City, CA, USA) according to the comparative threshold cycle (Ct) method following manufacturer's protocol (SYBR Premix Ex Taq ${ }^{\mathrm{TM}}$, TAKARA BIO INC., Otsu, Japan). Q-PCR was performed in a $20 \mathrm{ul}$ total reaction mixture in 96-well plates containing; $2 \mathrm{ul}$ of cDNA as template, $10 \mathrm{ul}$ of SYBER Green (Takara, Otsu, Japan), 0.4 ul of ROX dye (Takara, Otsu, Japan), and 0.8 ul of 10 pmol each of the forward and reverse primers. Thermal cycler conditions were $95^{\circ} \mathrm{C}$ for 30 seconds, followed by, $95^{\circ} \mathrm{C}$ for 10 seconds and $60^{\circ} \mathrm{C}$ for 30 seconds, repeated for 40 cycles. All quantitative RT-PCR products were visualized on $2 \%$ agarose gels to ensure single products. The A difference in expression between normal thyroid- gland tissue and sample $\mathrm{X}$ of an ACL is defined as follows:

$\Delta \mathrm{C}_{\mathrm{tX}}=\mathrm{C}_{\mathrm{t}-\mathrm{TCEAL} 4 \mathrm{X}}-\mathrm{C}_{\mathrm{t}-\mathrm{GAPDHX}}$

$\left(\mathrm{C}_{\mathrm{t} \text {-TCEAL4, GAPDH }}\right.$ are threshold cycles for amplification of TCEAL4 and GAPDH, respectively)

$\Delta \mathrm{C}_{\mathrm{tN}-\mathrm{ave}}=$ Sum of $\Delta \mathrm{C}_{\mathrm{tN} 1}$ to $\Delta \mathrm{C}_{\mathrm{tNN} 5} / 5$

(average of $\Delta \mathrm{Ct}$ of five normal thyroid tissues)

$\Delta \Delta \mathrm{C}_{\mathrm{tX}}=\Delta \mathrm{C}_{\mathrm{tX}}-\Delta \mathrm{C}_{\mathrm{tN} \_ \text {ave }}$

Expression ratio of TCEAL4 to normal thyroid tissue (sample $\mathrm{X} /$ average of five normal thyroid tissues $)=2^{(-\Delta \Delta \mathrm{Ct}}$ $\mathrm{x})$

\section{Expression of TCEAL4 in normal human tissues}

To confirm the expression status of TCEAL4 in human organs containing thyroid tissue, we performed SQ-PCR with Human MTC panel 1 \& 2 (BD Bioscience, Palo Alto, CA, USA), using SQ-PCR conditions described above.

\section{Results}

Expression of TCEAL4 in primary thyroid tissues

We examined the expression of TCEAL4 in 5 normal thyroid tissues, 5 PTCs, and 5 ATCs by SQ-PCR and Q-PCR. Expression of TCEAL4 was significantly down-regulated in
ATCs as compared to normal thyroid tissues and PTCs (Figure 1A and 1B). Clinical profiles of patients that had samples subjected to SQ-PCR are shown in Table 2.

\section{Down-regulation of TCEAL4 in ACLs}

We also investigated the expression of TCEAL4 in cell lines derived from 11 anaplastic thyroid cancers (ACLs) and five normal thyroid tissues by SQ-PCR and Q-PCR. Expression of TCEAL4 was markedly reduced in all ACLs as compared to normal thyroid tissue (Figure 2A and $2 \mathrm{~B}$ ). The expression ratio of GAPDH and TCEAL4 revealed that TCEAL4 was significantly under-expressed in ACLs.

\section{Expression of TCEAL4 in human cancer cell lines}

To assess whether the loss of expression of TCEAL4 was specific to ACLs, we examined TCEAL4 expression by SQPCR in 91 of cancer cell lines including differentiated thyroid cancers derived from papillary and follicular cancers. TCEAL4 expression was absent or under-expressed in 46 of 91 (51\%) cell lines examined, namely hepatic cell carcinomas, gastric cancers, colon cancers, ACLs, ovarian cancers, cervical cancers, lung cancers, urinary bladder cancers, renal cell carcinomas and neuroblastomas. Interestingly, expression of TCEAL4 was markedly reduced in ACLs as compared to DTCs (Figure 3).

\section{Expression of TCEAL4 in human normal tissues}

We also examined expression of TCEAL4 by SQ-PCR in normal human tissues including normal thyroid gland. TCEAL4 was expressed ubiquitously in all normal human tissues tested: heart, brain, placenta, lung, liver, skeletal muscle, kidney, spleen, pancreas, thymus, prostate, testis, ovary, small intestine, colon, leukocytes, and thyroid (Figure 4).

\section{Discussions and conclusion}

ATC has poor prognosis with a one year survival rate whereas PTC has a favorable prognosis [1-3]. It is well known that most ATCs arise from transformation of DTC [1-5], especially PTCs with repeated recurrences in regional lymph nodes [11]. Recently, molecular studies have been developed to analyze ATC. Mutations of TP53 $[14,15]$, beta-catenin [16], and BRAF [17] were detected at a high frequency in ATC. In addition, bcl-2 [18], cyclin D1 [19], Y-box binding protein (YB-1) [20], peroxisome proliferator-activated receptor- $\gamma$ (PPAR- $\gamma$ ) [21], maspin [22], and haemoglobin beta (HBB) [10] have been reported to 
Fig.1A TCEAL4 expression in primary PTC \&ATC

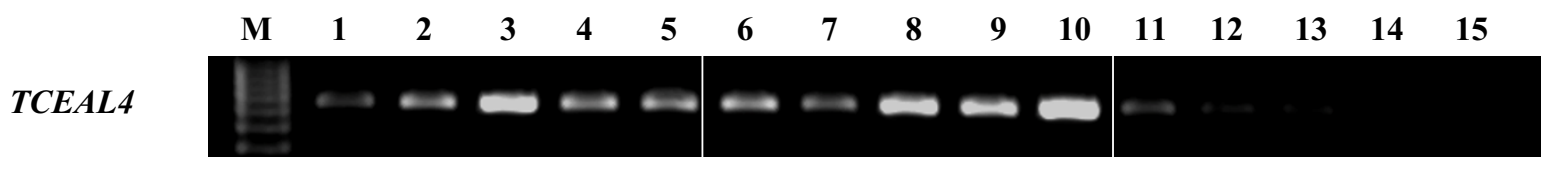

GAPDH

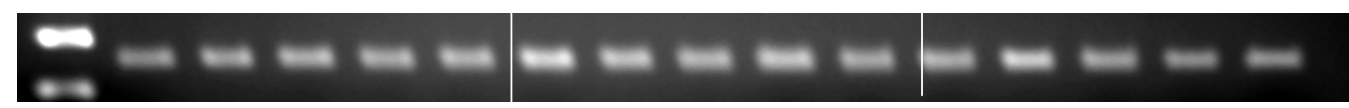

Normal Thyroid Tissues

PTC

ATC

Fig.1B Quantitative RT-PCR comparing the expression of TCEAL4
in Primary thyroid cancers \& Normal Thyroid Tissues

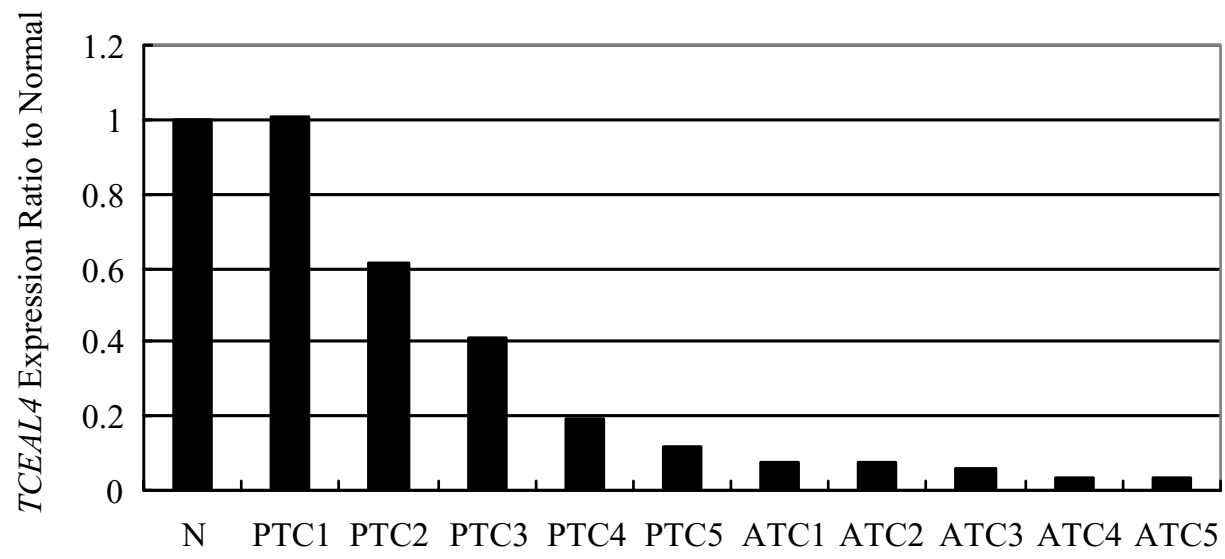

Figure I

(A) Decreased expression of TCEAL4 in ATCs as compared to normal thyroid tissues and PTCs as shown by SQ-PCR. The lane designations are as follows: $M$, size markers; I-5, normal thyroid samples, 6-10, primary papillary thyroid cancer samples, II-15, primary anaplastic thyroid cancer samples. (B) Results of quantitative RT-PCR. The average expression level of TCEAL4 among five normal thyroid tissues was set at I.00, then relative expression ratios were calculated between normal and cancerous tissues.

play an important role in anaplastic transformation of thyroid cancer. In a previous study, we found frequent allelic losses at 1q,9p, 11p, 11q, 17p, 19p and 22q in a panel of 21 ATCs suggesting that the region around these chromosome loci might harbor a tumor suppressor gene for ATC [23].

cDNA microarray technology has been developed to analyze a large number of genes in a biological sample at the same time. For the current study, we discovered genetic alterlation related to ATC carcinogenesis [6], and focused on TCEAL4 on the basis of CDNA microarray results. The protein encoded by this gene contains one transcription elongation factor A (TCEAL4), SII-related family motif. Yeh and Shatkin identified a gene from a Hela cell library encoding p21 that belongs to the SII family [7]. This gene may function as a nuclear phosphoprotein that modulates transcription in a promoter context-dependent manner.
Table 2: Clinical profile of patients selected for RT-PCR

\begin{tabular}{cccc}
\hline No. & Histotype & age & sex \\
\hline I & normal thyroid tissue & 25 & $\mathrm{~F}$ \\
2 & normal thyroid tissue & 44 & $\mathrm{~F}$ \\
3 & normal thyroid tissue & 38 & $\mathrm{~F}$ \\
4 & normal thyroid tissue & 23 & $\mathrm{~F}$ \\
5 & normal thyroid tissue & 36 & $\mathrm{~F}$ \\
6 & papillary thyroid cancer & 27 & $\mathrm{~F}$ \\
7 & papillary thyroid cancer & 23 & $\mathrm{~F}$ \\
8 & papillary thyroid cancer & 33 & $\mathrm{~F}$ \\
9 & papillary thyroid cancer & 53 & $\mathrm{~F}$ \\
10 & papillary thyroid cancer & 62 & $\mathrm{~F}$ \\
II & anaplastic thyroid cancer & 64 & $\mathrm{M}$ \\
12 & anaplastic thyroid cancer & 56 & $\mathrm{M}$ \\
13 & anaplastic thyroid cancer & 53 & $\mathrm{M}$ \\
14 & anaplastic thyroid cancer & 71 & $\mathrm{~F}$ \\
15 & anaplastic thyroid cancer & 68 & $\mathrm{M}$ \\
\hline
\end{tabular}


Fig.2A TCEAL4 expression in ACLs \& Normal Thyroid Tissues

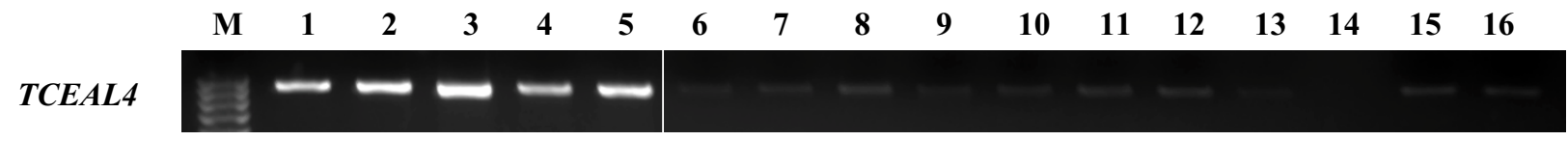
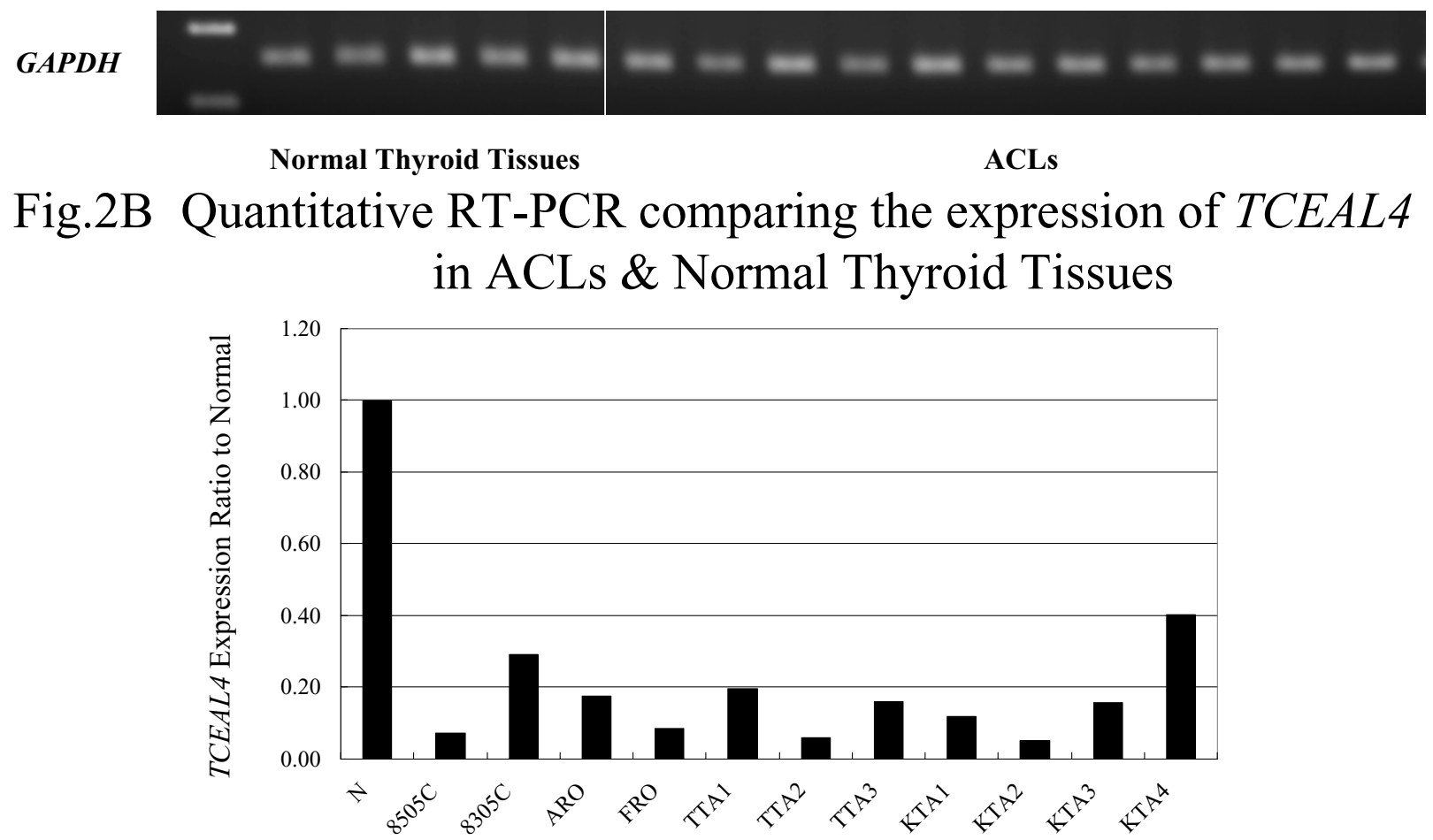

Figure 2

(A) Down-regulation of TCEAL4 in ACLs as compared to normal thyroid tissues as shown by SQ-PCR. The following are the lane designations: M, size marker; I-5, normal thyroid; 6, 8305c; 7, 8505c; 8, ARO; 9, FRO; I0, TTAI; II, TTA2; I2, TTA3; I3, KTAI; I4, KTA2; I5, KTA3; I6, KTA4. (B) Results of quantitative RT-PCR. TCEAL4 expression of normal thyroid is the average of five normal thyroid glands. When the expression of normal thyroid was settled as 1.00 , the ratio represented relative expression of TCEAL4 in the sample.

The Rous sarcoma virus long terminal repeat (RSV LTR) promoter was decreased by $\mathrm{p} 21$ indicating that both the zinc finger-like motif and the arginine/serine-rich region of p21 are essential for inhibition of RSV LTR function [8]. It was reported that $\mathrm{p} 21$, or TCEAL1 was expressed in all normal human tissues tested by northern blot analysis and this gene is located at Xq22.1 [9]. Multiple family members of TCEAL4 are located on chromosome X.

This study showed that mRNA expression of TCEAL4 was under-expressed in ATCs and ACLs as compared to normal thyroid tissues and DTCs. Interestingly, TCEAL4 was expressed ubiquitously in normal human tissues. Based on these results, we suggest that loss of TCEAL4 expression might be associated with development of ATC from DTC or normal thyroid glands. Unfortunately, we could not examine protein expression of TCEAL4 in thyroid tissues because an antibody of TCEAL4 was not available.

Gene silencing is caused by several reasons, including methylation of promoter region and loss of heterozygosity $(\mathrm{LOH})$. Methylation of DNA promoter region is one of the mechanisms for silencing transcription and inactivating tumor suppressor genes. In this study, we were unable to examine $\mathrm{LOH}$ because normal paired DNA samples were unavailable. Instead, we investigated the methylation status of the promoter region of TCEAL4 for 11 ACLs as described previously [10] and found that it was mainly 


\section{Fig.3 TCEAL4 Expression in 91 of Cancer Cell Lines}

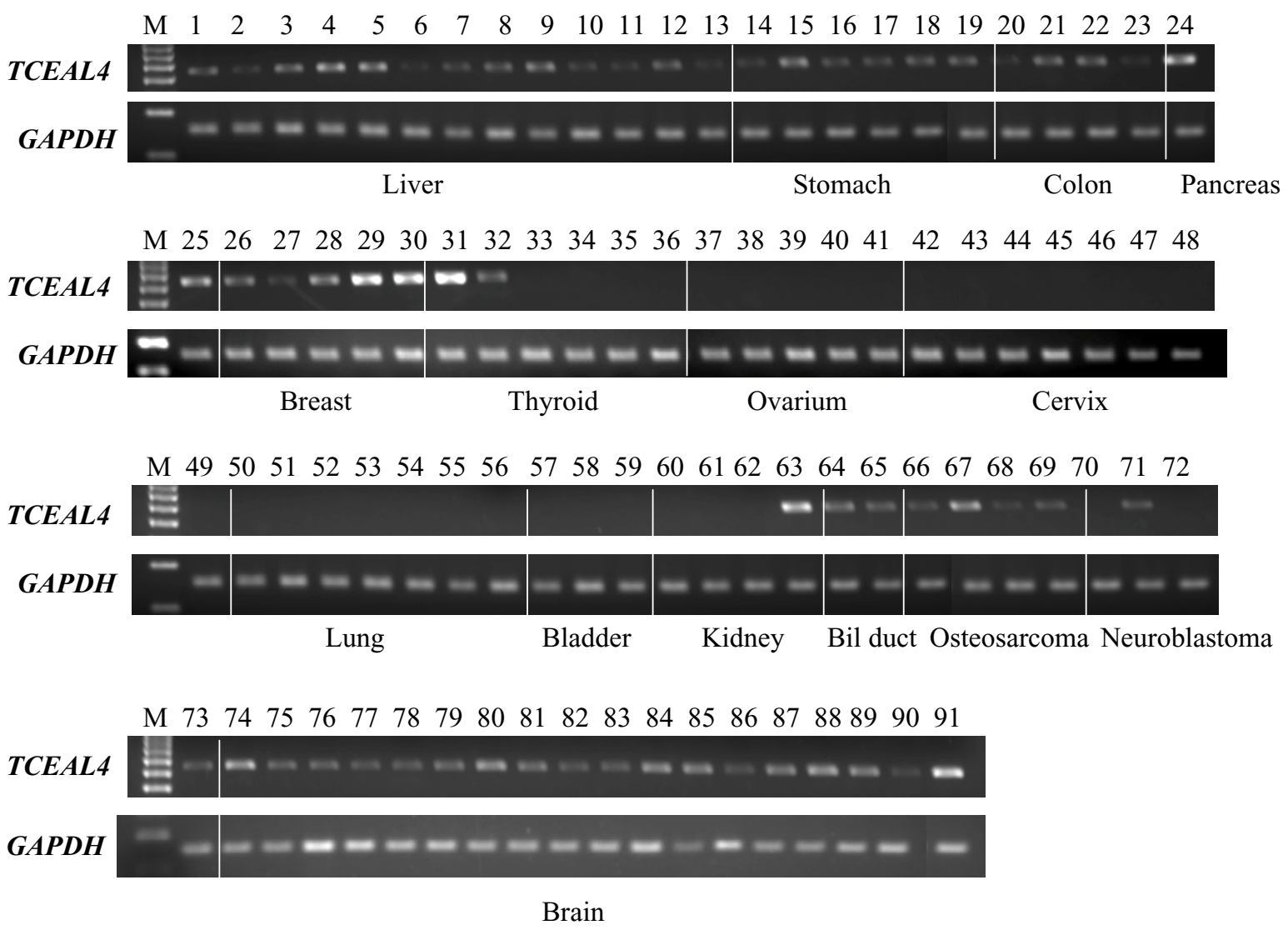

\section{Figure 3}

SQ-PCR analysis of the expression of TCEAL4 in 91 of cancer cell lines. The lanes are designated as: M, size marker; I, SK-HEPI; 2, Hep G2; 3, C-HC-4; 4, Hep-KANO CL2; 5, Hep-TABATA; 6, HuH7; 7, HTI7; 8, Li-7; 9, PLC/PRF/5; I0, Hep38; II, WRL68; I2, Chang Liver; I3, C3A; I4, HuGC-OOHIRA; I5, AZ52I; I6, H-III-TC; 17, SH-I0-TC; I8, MKN-7; 19, NUGC-4; 20, DLD-I; 2I, SW480; 22, HCT-I5; 23, WiDr; 24, MIA Paca2; 25, PK8; 26, MDA-MB-453; 27, CDLI500; 28, YMB-I-E; 29, MCF7; 30, HBLI00; 3I, WRO; 32, NPA; 33, ARO; 34, FRO; 35, 8505c; 36, 8305c; 37, CAOV-3; 38, SK-OV-3; 39, OVCAR-3; 40, OV-I063; 4I, OVK 18; 42, SIHA; 43, HT-3; 44, D98-AH2; 45, Hela TG; 46, Hela; 47, Ca Ski; 48, Me-I80; 49, Hela.P3; 50, RERF-LC AI; 5I, PC-I4; 52, A549; 53, EBC-I; 54, LU65; 55, LU99; 56, LK-2; 57, 5637; 58, T24; 59, EJ-I; 60, OS-RC-2; 6I, RCCIORGB; 62, VMRC-RCW; 63, Caki-I; 64, HuH-28; 65, TFK-I; 66, MG-63; 67, Saos02; 68, HuO-3NI; 69, U-2OS; 70, IMR32; 7I, NH-I2; 72, SCCH-26; 73, NB-I; 74, TE67I; 75, U-I38MG; 76, U-373MG; 77, U-II8MG; 78, KG-I-C; 79, GI-I; 80, U25I; 8I, SWI088; 82, Daoy; 83, DBTRG-05MG; 84, D283 Med; 85, AI72; 86, T98G; 87, u87MG; 88, u25IMG; 89, SNBI9; 90, uw 18; 91, uw228. 


\section{Fig.4 Expression of TCEAL4 in Normal Human Tissues}

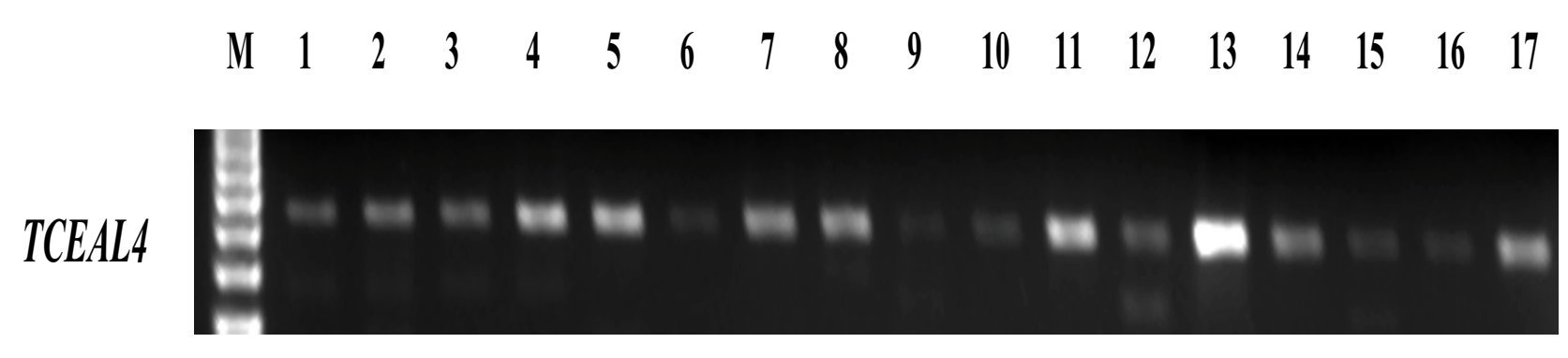

GAPDH

\section{Figure 4}

Expression of TCEAL4 in normal human tissues. The following are the lane designations: M, size marker; I, heart; 2, brain; 3, placenta; 4, lung; 5, liver; 6, skeletal muscle; 7, kidney; 8, spleen; 9, pancreas; I0, thymus; II, prostate; 12, testis; I3, ovary; I4, small intestine; 15, colon; 16, leukocytes; 17, thyroid.

hemi-methylated (the data was not shown). We suggest that methylation may be one of the mechanisms for the down-regulation of TCEAL4 in ATC and ACL.

In conclusion, this is the first study that describes of altered TCEAL4 expression in human cancer. The results suggest that loss of expression of TCEAL4 might play a role in anaplastic thyroid cancers. To confirm whether the activity of TCEAL4 would suppress cell survival in ATC, further functional analyses are required.

\section{Competing interests}

The author(s) declare that they have no competing interests.

\section{Authors' contributions}

JA carried out the molecular genetic studies and drafted the manuscript. $\mathrm{MO}$ participated in the design of the study and helped to draft the manuscript. JO helped to participate in the design of the study. SY helped to participate in the molecular genetic studies. $\mathrm{MH}$ and KI provided thyroid materials. AY donated anaplastic thyroid cancer cell lines. KS participated in coordination of the study. All authors read and approved the final manuscript.

\section{Acknowledgements}

This work was supported by special grants for Strategic Advanced Research on "Cancer" from the Ministry of Education, Science, Sports and Culture of Japan; and by a Research for the Future Program Grant of The Japan Society for the Promotion of Science. 


\section{References}

I. Venkatesh YS, Ordonez NG, Schultz PN, Hickey RC, Goepfert H, Samaan NA: Anaplastic carcinoma of the thyroid. A clinicopathologic study of 121 cases. Cancer 1990, I5:32I-330.

2. Demeter JG, De Jong SA, Lawrence AM, Paloyan E: Anaplastic thyroid carcinoma: risk factors and outcome. Surgery 1991, I I 0:956-96I.

3. Passler C, Scheuba C, Prager G, Kaserer K, Flores JA, Vierhapper H, Niederle B: Anaplastic (undifferentiated) thyroid carcinoma (ATC). A retrospective analysis. Langenbecks Arch Surg 1999, 384:284-293.

4. Wiseman SM, Loree TR, Rigual NR, Hicks WL Jr, Douglas WG, Anders : Anaplastic transformation of thyroid cancer: review of clinical, pathologic, and molecular evidence provides new insights into disease biology and future therapy. Head Neck 2003, 25:662-670.

5. Hunt JL, Tometsko M, LiVolsi VA, Swalsky P, Finkelstein SD, Barnes EL: Molecular evidence of anaplastic transformation in coexisting well-differentiated and anaplastic carcinomas of the thyroid. Am J Surg Pathol 2003, 27:1559-I564.

6. Onda M, Emi M, Yoshida A, Miyamoto S, Akaishi J, Asaka S, Mizutani K, Shimizu K, Nagahama M, Ito K, Tanaka T, Tsunoda T: Comprehensive Gene Expression Profiling of Anaplastic Thyroid Cancers with cDNA Microarray of 25,344 Genes. Endocr Relat Cancer 2004, I I:843-54.

7. Yeh $\mathrm{CH}$, Shatkin AJ: A HeLa-cell-encoded $\mathbf{p} 2 \mathrm{I}$ is homologous to transcription elongation factor SII. Gene 1994, I 43:285-287.

8. Yeh $\mathrm{CH}$, Shatkin AJ: Down-regulation of Rous sarcoma virus long terminal repeat promoter activity by a HeLa cell basic protein. Proc Nat Acad Sci 1994, 9 I: I I002-I I 006.

9. Pillutla RC, Shimamoto A, Furuichi Y, Shatkin AJ: Genomic structure and chromosomal localization of TCEALI, a human gene encoding the nuclear phosphoprotein p2 I/SIIR. Genomics 1999, 56:217-220.

10. Onda M, Akaishi J, Asaka S, Okamoto J, Miyamoto S, Mizutani K, Yoshida A, Ito K, Emi M: Decreased expression of haemoglobin beta (HBB) gene in anaplastic thyroid cancer and recovery of its expression inhibits cell growth. $\mathrm{Br} /$ Cancer 2005, 20:2216-2224

II. Ozaki O, Ito K, Mimura T, Sugino K, Ito K: Anaplastic transformation of papillary thyroid carcinoma in recurrent disease in regional lymph nodes: a histologic and immunohistochemical study. J Surg Oncol 1999, 70:45-48.

12. Lam KY, Lo CY, Chan KW, Wan KY: Insular and anaplastic carcinoma of the thyroid. A 45-year comparative study at a single institution and a review of the significance of p53 and p2 I. Ann Surg 2000, 23 I:329-338.

13. Saunders CA, Nayar R: Anaplastic spindle-cell squamous carcinoma arising in association with tall-cell papillary cancer of the thyroid: A potential pitfall. Diagn Cytopathol 1999, 2 I:4I3-4 18. Erratum in: Diagn Cytopathol 2000, 22:136

14. Nakamura T, Yana I, Kobayashi T, Shin E, Karakawa K, Fujita S, Miya A, Mori T, Nishisho I, Takai S: p53 gene mutations associated with anaplastic transformation of human thyroid carcinomas. Jpn J Cancer Res 1992, 83: I293-1298.

15. Moretti F, Farsetti A, Soddu S, Misiti S, Crescenzi M, Filetti S, Andreoli $M$, Sacchi $A$, Pontecorvi $A$ : $\mathbf{p 5 3}$ re-expression inhibits proliferation and restores differentiation of human thyroid anaplastic carcinoma cells. Oncogene 1997, I3:729-740.

16. TGarcia-Rostan GT, TTallini GT, THerrero AT, TD'Aquila TGT, TCarcangiu MLT, TRimm DLT: Frequent Mutation and Nuclear Localization of $\beta$-Catenin in Anaplastic Thyroid Carcinoma. Cancer Res 1999, 59:181|-1815.

17. Nikiforova MN, Kimura ET, Gandhi M, Biddinger PW, Knauf JA, Basolo F, Zhu Z, Giannini R, Salvatore G, Fusco A, Santoro M, Fagin JA, Nikiforov YE: BRAF mutations in thyroid tumors are restricted to papillary carcinomas and anaplastic or poorly differentiated carcinomas arising from papillary carcinomas. J Clin Endocrinol Metab 2003, 88:5399-5404.

18. Pilotti S, Collini P, Rilke F, Cattoretti G, Del Bo R, Pierotti MA: Bcl2 protein expression in carcinomas originating from the follicular epithelium of the thyroid gland. I Pathol 1994, I 72:337-342.

19. Wang S, Lloyd RV, Hutzler MJ, Safran MS, Patwardhan NA, Khan A: The role of cell cycle regulatory protein, cyclin $\mathrm{DI}$, in the progression of thyroid cancer. Mod Pathol 2000, 13:882-887.
20. Ito $Y$, Yoshida $H$, Shibahara K, Uruno T, Nakano K, Takamura $Y$, Miya A, Kobayashi K, Yokozawa T, Matsuzuka F, Uchimi T, Kuwano M, Miyoshi E, Matsuura N, Kuma K, Miyauchi A: Y-box binding protein expression in thyroid neoplasms: its linkage with anaplastic transformation. Pathol Int 2003, 53:429-433.

21. Hayashi N, Nakamori S, Hiraoka N, Tsujie M, Xundi X, Takano T, Amino N, Sakon M, Monden M: Antitumor effects of peroxisome proliferator activate receptor gammma ligands on anaplastic thyroid carcinoma. Int J Oncol 2004, 24:89-95.

22. Ito $Y$, Yoshida H, Tomoda C, Uruno T, Takamura Y, Miya A, Kobayashi K, Matsuzuka F, Matsuura N, Kuma K, Miyauchi A: Maspin expression is directly associated with biological aggressiveness of thyroid carcinoma. Thyroid 2004, I 4: I3-18.

23. Kitamura Y, Shimizu K, Tanaka S, Ito K, Emi M: Allelotyping of anaplastic thyroid carcinoma: frequent allelic losses on Iq, 9p, I I, I 7, I 9p, and 22q. Genes Chromosomes Cancer 2000, 27:244-225.

\section{Pre-publication history}

The pre-publication history for this paper can be accessed here:

http://www.biomedcentral.com/1471-2407/6/260/pre pub
Publish with Bio Med Central and every scientist can read your work free of charge

"BioMed Central will be the most significant development for disseminating the results of biomedical research in our lifetime. "

Sir Paul Nurse, Cancer Research UK

Your research papers will be:

- available free of charge to the entire biomedical community

- peer reviewed and published immediately upon acceptance

- cited in PubMed and archived on PubMed Central

- yours - you keep the copyright
BioMedcentral 